\title{
ANALISIS PERLINDUNGAN MEREK DAGANG \\ TERHADAP SENGKETA NEGARA ISLE OF MAN DAN WEN KEN DRUG CO. PTE LTD
}

\author{
Riska Luneto \& Aldilla Dika \\ UIN Alauddin Makassar \& Universitas Gadjah Mada \\ Email : riska105@gmail.com \& al_dilla_88@yahoo.com
}

\begin{abstract}
ABSTRACK
Protection of trademarks (goods / services) is one of the important things for every inventor. The success of the WTO as an organization that oversees cooperation in the field of trade has an important role in the struggle that was resolved in the field of trade, in accordance with the agreement in the TRIPs which discussed Intellectual Property that was sponsored both nationally and internationally. The damaged trademark case by the Wen Ken Group Company later became an example of violation of the agreement, when the trademark product / service that was registered did not conflict with the logo, symbol or symbol of an ideology or the State. The resolution of this dispute is then still a polemic in Indonesia because the decisions made are not in accordance with the provisions in force, so they are approved by the WTO.
\end{abstract}

Keywords: Intellectual Property Rights, WTO, TRIPs, Trademarks, Disputes

\section{PENDAHULUAN}

Intellectual Property Right (Hak Kekayaan Intelektual-HKI) merupakan istilah perlindungan hukum terhadap karya intelektual dari seorang inventor (Utomo 2009). Dalam kesepakatan negara anggota World Trade Organization (WTO) melalui Uruguay Round disepakati perjanjian mengenai Trade Related Intellectual Property Rights (TRIPS) yang juga sudah mengatur hal-hal mengenai perlindungan Kekayaan Intelektual dan berlaku untuk seluruh anggota. Perjanjian ini mencangkup perlindungan terhadap Copyright and Related Rights, Trademarks, Geographical Indications, Industrial Designs, Patents, Patents, Protection of Undisclosed Information, Control of Anti-Competitive Practices in Contractual Licences (World Trade Organization 2018).

Setiap peelindungan mengenai Kekayaan Intelektual dapat diberlakukan melalui syaratsyarat tertentu, seperti misalnya perlindungan terhadap Merek Dagang dari suatu produk barang ataupun jasa. Berlakunya perlindungan terhadap Merek Dagang disetujui apabila produk/jasa tersebut tidak memiliki kemiripan dengan produk lain, bertentangan dengan peraturan perundang-undangan yang berlaku, moralitas agama, kesusilaan, atau ketertiban umum ataupun memiliki kemiripan dengan lambang dari Negara (DJKI Kemenkumham 2001). Kasus ini kemudian berkaitan langsung dengan pelanggaran yang dilakukan oleh satu satu produk minuman kesehatan yang terjadi pada tahun 2013, yaitu minuman larutan Cap Kaki Tiga. 
Larutan penyegar Cap Kaki Tiga sendiri adalah sebuah merek dagang yang telah berdiri sejak tahun 1937 di Singapura untuk memenuhi kebutuhan masyarakat akan obat-obatan dasar, tahun 1978 Cap Kaki Tiga mulai memasuki pasar di Indonesia sebagai minuman pereda panas dalam (Wen Ken Group 2018). Ditahun yang sama, sebuah gugatan dilayangkan oleh salah seorang warga negara berkebangsaan Inggris, Russel Vince terhadap logo Cap Kaki Tiga yang dianggap sebagai bentuk penjiplakan terhadap lambang negara Isle of Man. Isle of Man sendiri merupakan wilayah yang memiliki kedaulatan sendiri, dimana untuk urusan luar negeri yang berhubungan dengan Negara lain, Isle of Man diwakili oleh Negara Inggris (Isle of Man Government 2009).

Dalam kasus ini Vince berpegang pada Pasal 68 Undang Undang Merek Republik Indonesia yang berbunyi: "Gugatan Pembatalan Pendaftaran Merek dapat diajukan oleh pihak yang berkepentingan berdasarkan alasan sebagaimana dimaksud dalam Pasal 4, 5 dan 6”; gugatan merek Cap Kaki Tiga ada karena dianggap merupakan tiruan atau menyerupai lambang negara Isle of Man yang digunakan dalam bendera dan/atau mata uang negara yaitu logo lingkaran dengan tiga kaki didalamnya, sementara Isle of Man berdiri jauh sebelum merek cap kaki tiga terdaftar di Indonesia ataupun negara asalnya.

Dalam era perdagangan global, sejalan dengan konvensi-konvensi internasional yang telah diratifikasi Indonesia, peranan merek menjadi sangat penting terutama dalam menjaga persaingan usaha yang sehat. Dalam kasus ini ada beberapa putusan yang kemudian dikeluarkan oleh Pengadilan Niaga, pada putusan pertama Pengadilan Niaga membenarkan bahwa Produk Wen Ken Group memang melakukan beberapa poin kesalahan berdasarkan aturan Mere Dagang baik yang berlaku di Indonesia maupun TRIPs dan Konvensi Paris, akan tetapi kemudian Pengadilan menyetujui banding yang dilakukan oleh Wen Ken Group. Hal inilah yang kemudian menarik bagi penulis untuk kemudian mengkaji perlindungan Merek berdasarkan perjanjianperjanjian yang telah disepakati dalam WTO.

\section{KERANGKA ANALISIS}

Dalam tulisan ini, penulis menggunakan analisis perlindungan hukum terhadap segala jenis bentuk Kekayaan Intelektual khususnya yang mengatur mengenai Merek Dagang berdasarkan perjanjian kerjasama perdagangan dunia. WTO sendiri telah mengatur bagaimana kemudian kerjasama baik perdagangan, tariff maupun perlindungan terhadap Intellectual Property Right $(I P R)$. Dalam penelitian ini penulis kemudian mengadopsi konsep mengenai perlindungan Merek Dagang berdasarkan: 


\section{TRIPs Agreement}

Uruguay Round yang dilakukan pada tahun 1984-1994 kemudian menyepakati perlindungan IPR yang berlaku bagi setiap Negara anggota. Dalam putaran ini setiap-negara anggota kemudian diperkenalkan landasan hukum mengenai Kekayaan Intelektual yang seharusnya dilindungi bersama, baik dari penlindungan Paten, Indikasi Geografis, Merek, Tata Letak dan beberapa perlindungan KI lainnya. Salah satu poin penting dalam penelitian ini adalah bagaimana kemudian TRIPs berdampak pada perlindungan Merek Dagang dan Simbol/Lambang satu Negara.

2. UU Republik Indonesia No. 15 Tahun 2001 Tentang Merek

Dalam UU RI No. 15 Pemerintah mengadopsi berbagai hukum internasional mengenai perlindungan Merek. Didalamnya Pemerintah menjelaskan bagaimana kemudian suatu Merek dapat berlaku dan terdaftar dalam suatu Negara, selain itu berbagai ketentuan-ketentuan seperti pembatalan maupun sanksi bagi pelanggaran merek termaktub didalamnya.

3. Paris Convention

Sebagai landasan hukum bagi perlindungan Kekayaan Intelektual, Konvensi Paris kemudian penulis jadikan sebagai konsep analisis dalam melihat sengketa yang ada. Dalam Article 6 (1) Paris Convention misalnya dijelaskan "Every trademark duly registered in the country of origin shall be accepted for filing and protected as is in the other countries of the Union, subject to the reservations indicated in this Article. Such countries may, before proceeding to final registration, require the production of a certificate of registration in the country of origin, issued by the competent authority. No authentication shall be required for this certificate" (WIPO 1994). Dalam kasus ini kemudian penulis meninjau sejauh mana Konvensi Paris melindungi Merek Dagang suatu produk barang/jasa.

\section{METODE PENELITIAN}

Penelitian ini merupakan penelitian kualitatif dengan menggunakan data primer dan sekunder yang penulis dapatkan dari UU Merek Dagang RI, TRIPS, Paris Convention juga berdasarkan wawancara kepada salah saksi ahli dalam sengketa ini. Sumber data yang penulis gunakan adalah berdasarkan dokumen-dokumen mengenai aturan maupun putusan yang diberlakukan oleh pemerintah. Dalam tulisan ini, penulis menggunakan metode studi pustaka, dengan cara mengumpulkan berbagai bahan terkait sengketa maupun UU/Perjanjian terkait Merek Dagang baik yang berlaku Nasional maupun Internasional. Kemudian dengan data primer dan sekunder 
yang penulis dapatkan, kami menganalisis sejauh mana kasus sengketa Merek Dagang tersebut jika dikaitkan dengan berbagai kajian perlindungan hukum yang berlaku.

\section{PEMBAHASAN}

Merek Dagang merupakan salah ciri khas atau tanda yang membedakan satu produk dengan produk lain, keberadaan Merek Dagang juga dapat mempermudah konsumen dalam identifikasi produk yang mereka inginkan (Djumhana 2006), sehingga terdaftarnya Merek Dagang akan sangat menguntungkan bagi produsen dan juga konsumen, oleh sebab itu kemudian sengketa mengenai pelanggaran Merek Dagang akan sangat berpengaruh terhadap satu perusahaan khusunya pada nilai ekonomi suatu produk (Dianggoro 1997). Era globalisasi dan terbukanya pasar serta bebas masuknya produk-produk asing kedalam suatu Negara menuntut menjaga agar setiap produk dan sumber daya yang dihasilkan layak dan mampu bersaing secara global dan memiliki perlindungan hukum (Peter 2017).

Dalam UU No. 15 Tahun 2001 Pasal 1 tentang Merek, dijelaskan bahwa Merek adalah “tanda yang berupa gambar, nama, kata, huruf-huruf, angka-angka, susunan warna, atau kombinasi dari unsur-unsur tersebut yang memiliki daya pembeda dan digunakan dalam kegiatan perdagangan barang atau jasa". Sementara Merek Dagang adalah "Merek yang digunakan pada barang yang diperdagangkan oleh seseorang atau beberapa orang secara bersama-sama atau badan hukum untuk membedakan dengan barang-barang sejenis lainnya”. Kemudian Merek Jasa adalah "Merek yang digunakan pada jasa yang diperdagangkan oleh seseorang atau beberapa orang secara bersama-sama atau badan hukum untuk membedakan dengan jasa-jasa sejenis lainnya” (DJKI Kemenkumham 2001).

WTO adalah satu satu organisasi perdagangan dunia yang memiliki anggota hampir seluruh Negara yang ada, kesepakatan mengenai kerjasama perdagangan diatur didalamnya begitu juga mengenai aturan perlindungan pada setiap Kekayaan Intelektual baik yang dimiliki perorangan maupun kelompok (Jened, Trademark Law 2015). Pada Putaran Uruguay tahun 1986-1994 yang merupakan agenda rutin bagi setiap Negara anggota untuk membahas mengenai kesepakatan-kesepakatan, disetujui mengenai aturan Kekayaan Intelektual yaitu TRIPs (World Trade Organization 2017). Merek dalam TRIPs merupakan “Any sign, or any combination of signs, capable of distinguishing the goods or services of one undertaking from those of other undertakings, shall be capable of constituting a trademark” (TRIPs 1994) .

Indonesia mengkategorikan pelanggaran terkait Kekayaan Intelektual sebagai salah satu bentuk tindak pidana (Sulistiyono 2004). Pelanggaran merek ini terjadi antara dua pihak yang 
terlibat. Russel Vince sebagai warga Negara berkebangsaan Inggris melakukan gugatan terhadap perusahaan yang menurutnya melanggar kesepakatan aturan mengenai Merek dala UU No. 15 Tahun 2001, TRIPs Agreement, maupun Konvensi Paris. Menurutnya setiap merek yang didaftarkan pada hakikatnya tidak dapat berbentuk menyerupai logo/lambang satu Negara, dalam UU No. 15 Tahun 2001 Pasal 5 dan Pasal 6 juga dijelaskan mengenai proses pendaftaran. Hal inilah yang kemudian menjadi alasan Vince untuk kemudian melakukan gugatan tersebut.

\section{Isle of Man}

Isle of Man adalah salah satu pulau yang dikenal dengan sebutan Mann, keberadaan pulau ini telah dihuni oleh sebagian masyarakat campuran yang berada dekat dengan pulau tersebut, seperti Negara persemakmuran Inggris. Berdasarkan sejarah yang teryulis pada Putusan Mahkamah Agung mengenai sejarah Isle of Man dijelaskan bahwa pada abad ke-9, tentara Norsemen Kerajaan Isle, adalah Magnus III, yang merupakan Raja Norwegia juga dikenal sebagai Raja Mann antara pada tahun 1099 dan 1103. Pada 1266, pulau ini menjadi bagian Skotlandia di bawah Perjanjian Perth, setelah diperintah oleh Norwegia. Setelah melewati berbagai perebutan kekuasaan antara Inggris dan Norwegia, wilayah tersebut akhirnya jatuh dibawah pemerintahan United Kingdom (Isle of Man Government 2009).

Pada dasarnya Isle of Man adalah negara berdaulat dengan Tynwald Parliament sebagai pusat pemerintahan domestik, akan tetapi Negara tersebut masih menggantungkan pertahanan luar negeri pada Inggris, Inggris merupakan representative dari negara tersebut begitu pula dalam urusan di forum internasional, selain berada dibawah pemerintahan Inggris Negara ini juga ikut dalam peraturan hukum Inggris (Mahkamah Agung 2015).

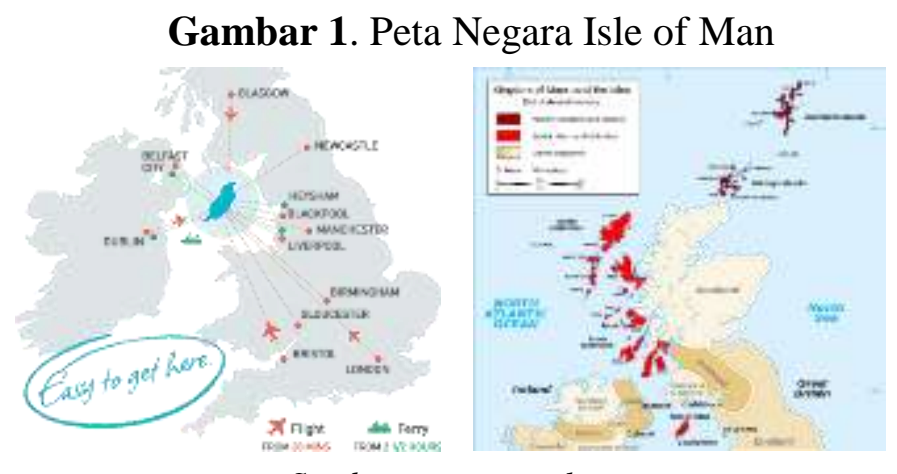

Sumber: $\underline{w w w . g o o g l e . c o m}$

Isle of Man menggunakan lambang/simbol kuno bernama Triskelion (Kaki Tiga), yang semuanya memiliki makna tersendiri dan dilengkapi bintang pada setiap sudutnya. Simbol 
Triskelion juga dihunakan sebagai publikasi pemerintah, mata uang, bendera, dan lain-lain. Ketiga kaki secara langsung berhubungan dengan semboyan Isle of Man yaitu "Quocunque Jeceris Stabit”, yang artinya Kemanapun anda melemparnya, ia akan berdiri. Semboyan ini kemudian berjalan lurus dengan konsep hidup warga Negara Isle of Man (Mahkamah Agung 2015). Kesamaan dari lambang ini yang kemudian membawa gugatan terhadap Cap Kaki Tiga di Pengadilan Niaga Jakarta.

\section{Wen Ken Drug Co.Pte (Cap Kaki Tiga)}

Larutan merek Cap Kaki Tiga pertama kali didirikan di Singapura pada tahun 1937 oleh Wen Ken Drug Co (Pte) Ltd atas dasar kebutuhan masyarakat terhadap obat-obatan, seiring berjalannya waktu jenis obatan berupan Larutan Penyegar menjadi salah satu bentuk inovasi perusahaan dalam kompetisi. Sehingga, perusahaan berinisiatif untuk membuat sebuah minuman daya tahan tubuh yang diberi naman Larutan Penyegar Cap Kaki tiga dan pada tahun 1978 produk ini mulai memasuki pasar Indonesia dan didaftarkan merek dagangnya pada tahun 1989. Lambang dari produk Cap Kaki Tiga sendiri memiliki makna (Wen Ken Group 2018);

- Kaki yang terarah ke atas melambangkan kehidupan yang harus selalu terarah pada ajaran tentang kebenaran yang bersumber dari yang maha kuasa.

- Kaki yang berpijak ketanah melambangkan kerja keras yang harus dilakukan untuk mencapai sebuah kesuksesan.

- Kaki yang bersimpuh melambangkan kerendahan hati yang harus dimiliki setiap orang yang berakhlak mulia.

\section{Gambar 2. Logo Larutan Cap Kaki Tiga}

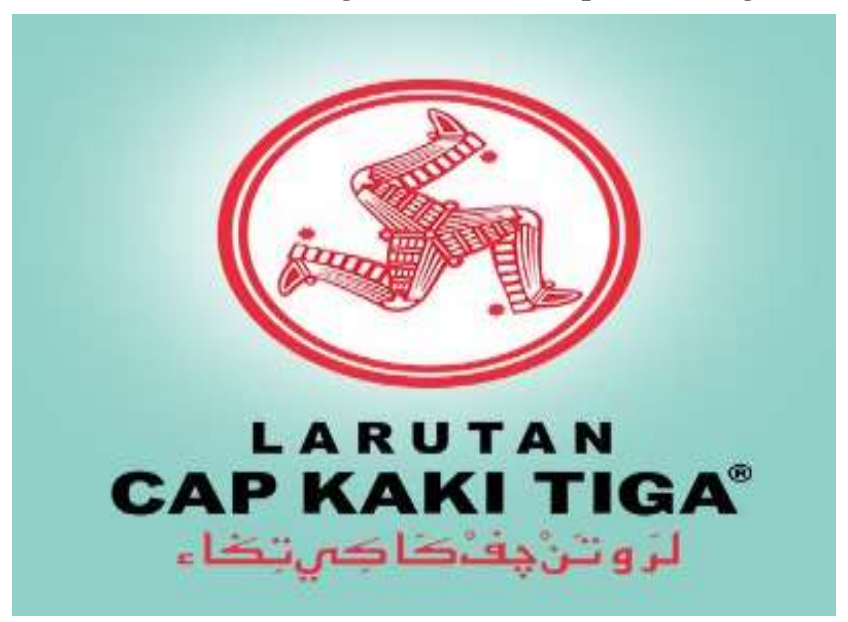

Sumber: (Wen Ken Group 2018) 
Di Indonesia, produk ini telah berdiri sejak tahun 70-an, yang kemudian dalam proses beredarnya produk-produk dari perusahaan tersebut tidak luput dari pendaftaran Merek produk mereka sejak tahun 1989 dengan berbagai kategori perlindungan, sehingga kemudian peredaran produk Cap Kaki Tiga pada dasarnya dilindungi secara hukum di Indonesia.

\section{Analisis UU. No 15 Tahun 2001}

Tahun 2014 Russel Vince seorang warga Negara Inggris melalui kuasa hukumnya di Indonesia melakukan permohonan pembatalan Merek suatu produk dengan berpegang pada Pasal 68 UU No. 15 Tahun 2001.

1) Gugatan pembatalan pendaftaran Merek dapat diajukan oleh pihak yang berkepentingan berdasarkan alasan sebagaimana dimaksud dalam Pasal 4, Pasal 5, atau Pasal 6.

2) Pemilik Merek yang tidak terdaftar dapat mengajukan gugatan sebagaimana dimaksud pada ayat (1) setelah mengajukan Permohonan kepada Direktorat Jenderal. (3)

3) Gugatan pembatalan sebagaimana dimaksud pada ayat (1) diajukan kepada Pengadilan Niaga.

Disamping itu, loga/lambnag Kaki Tiga sudah digunakan jauh sebelum adanya produk Wen Ken Group. Sebagai warga Negara Inggris, yang mengatur hubungan luar negeri ataupun representative dari Isle of Man Vince merasa perlu melakukan tindakan pelaporan karena menganggap bahwa hal tersebut berkaitan dengan kedaulatan suatu bangsa. Indonesia sebagai Negara yang memiliki hak edar produk dengan logo tersebut memiliki peran dalam mengambil keputusan, hal ini dapat berakibat pada hubungan antar kedua Negara Indonesia-Isle of Man meskipun keduanya tidak memiliki hubungan diplomasi langsung. Disatu sisi Isle of Man yang memiliki Inggris sebagai bagian penting dalam system pemerintahannya yang kemudian dapat mengganggu hubungan diplomatic tersebut.

Gambar 3. Logo Cap Kaki Tiga dan Lambang Negara Isle of Man

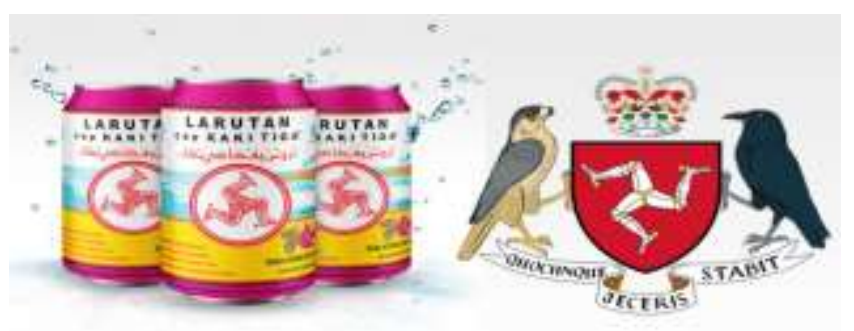

Sumber: www.gooogle.com 
Selain Pasal 68, Vince melalui kuasa hukumnya juga melihat pada Pasal 69 ayat (2) UU Merek bahwa :"Gugatan pembatalan dapat diajukan tanpa batas waktu apabila Merek yang bersangkutan bertentangan dengan moralitas agama, kesusilaan, atau ketertiban umum. Sebagaimana dari diatas, tindakan Cap Kaki Tiga yang menggunakan lambang negara Isle of Man sebagai merek dagang dianggap tidak sesuai dengan ketentuan dan perjanjian yang berlaku dala TRIPs, sehingga gugatan yang dilayangkan sudah pada tahap kewajaran. Jika ditinjau berdasarkan UU No. 15 Pasal 6 Ayat 3 sudah mengatur bagaimana seharusnya suatu Merek layak untuk diberi perlindungan, Merek dapat ditolak perlindungannya apabila (DJKI Kemenkumham 2001):

a) Merupakan atau menyerupai nama orang terkenal, foto, atau nama badan hukum yang dimiliki orang lain, kecuali atas persetujuan tertulis dari yang berhak;

b) Merupakan tiruan atau menyerupai nama atau singkatan nama, bendera, lambang atau simbol atau emblem negara atau lembaga nasional maupun internasional, kecuali atas persetujuan tertulis dari pihak yang berwenang;

c) Merupakan tiruan atau menyerupai tanda atau cap atau stempel resmi yang digunakan oleh negara atau lembaga Pemerintah, kecuali atas persetujuan tertulis dari pihak yang berwenang.

Penggunaan merek Cap Kaki Tiga pada produk minuman ini juga dinilai akan berdampak pada hubungan negara baik Inggris-Indonesia maupun Isle of Man-Indonesia yang sebelumnya tidak berkonflik justru akan berdampak sebaliknya jika hal tersebut dibiarkan dan tidak ditindak lanjuti. Selain itu, sengketa ini juga bukan tidak mungkin akan tidak berpengaruh terhadap perkembangan perekonomian ataupun kesepakatan/perjanjian perdagangan negaranegara terkait, Indonesia yang dalam kasus ini dapat dikatakan sebagai negara turut tergugat juga akan mengalami tekanan politik karena dinilai lalai dalam memberlakukan IPR atau izin merek dagang di negaranya (Indriyanto and Yusnita 2016).

Pengajuan pembatalan merek pada dasarnya dapat dilakukan oleh pihak-pihak yang menjadi perwakilan ataupun yang memiliki hubungan langsung dengan Merek yang bersengketa dalam jangka waktu 5 tahun sejak terdaftarnya merek tersebut. Sebagai bagian dari Kekayaan Intelektual, perlindungan Merek berlaku jika produk/jasa telah didaftarkan disatu Negara sesuai permintaan/permohonan pihak terkait (Kaligis 2012). Dalam UU No.15 disimpulkan bahwa terdapat beberapa prinsip dan ketentuan Merek (Utomo 2009):

1. Merek adalah sebuah tanda yang membedakan sebuah produk barang/jasa

2. Perlindungan Merek diberikan atau permohonan 
3. Pihak yang mengajukan permohonan tidak dibatasi, baik individu maupun kelompok atau badan hukum

4. Jangka waktu perlindungan dapat diperpanjang berdasarkan permohonan

5. UU Merek mengatur first to file pada hal ini

6. Penghapusan Merek dapat terjadi karena empat kemungkinan; prakarsa DJHKI, permohonan pemilik Mere, putusan pengadilan dan tidak adanya perpanjangan perlindungan.

Berdasarkan beberapa legal standing yang diajukan Vince melalui kuasa hukumnya, pemerintah Indonesia yang dalam hal ini ada Pengadilan Niaga Republik Indonesia mengeluarkan putusan dalam kasus tersebut. tahun 2015 Mahkamah Agung mengeluarkan putusan No. 85 PK/Pdt.Sus-HKI /2015 bahwasanya:

a) Menyatakan bahwa seluruh merek dagang "Cap Kaki Tiga” atas nama Tergugat menyerupai atau merupakan tiruan dari Lambang/Simbol/ Emblem/ Mata Uang Isle of Man

b) Membatalkan atau Setidak-tidaknya menyatakan batal Seluruh Sertifikat Merek "Cap Kaki Tiga” atas nama Tergugat dan mencoretnya dari Daftar Umum Merek Direktorat Jenderal Hak Kekayaan Intelektual dengan segala akibat hukumnya atas SertifikatSertifikat Merek

c) Memerintahkan Tergugat untuk menghentikan produksi, distribusi, dan promosi, serta menarik dari peredaran atas produk-produk yang mengandung Unsur-unsur dalam Sertifikat-Sertifikat Merek.

Gambar 4. Bendera dan Uang Kertas Isle of Man
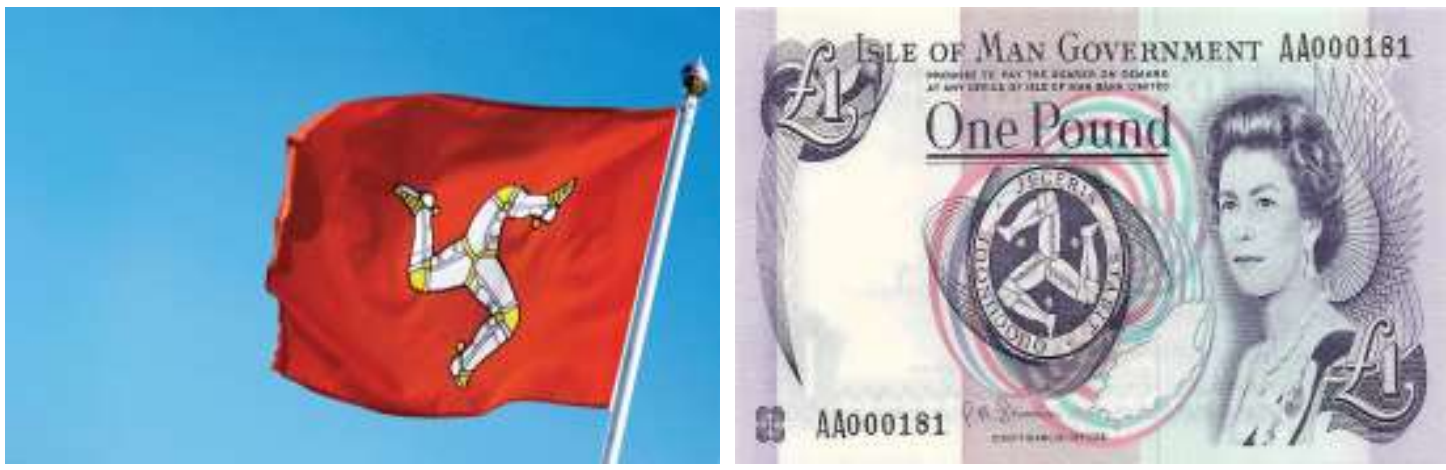

Sumber: (Mahkamah Agung 2015)

Akan tetapi, permasalahan lain muncul ketika pihak Cap Kaki Tiga mengeluarkan sanggahan kepada MA mengenai latar belakang penggugat, agar gugatan penggugat dibatalkan 
oleh pengadilan dengan alasan : Bahwa Penggugat ternyata hanyalah seorang warga negara Inggris yang sama sekali bukanlah subjek hukum yang ditunjuk oleh Pemerintah Inggris untuk mewakili Negara Isle of Man untuk berperkara dengan Tergugat di Indonesia sehingga Penggugat tidak memilik kapasitas untuk menggugat ; Dengan demikian, gugatan Penggugat harus dinyatakan tidak dapat diterima (niet ontvankelijke verklaard) karena Penggugat tidak memiliki kapasitas untuk menggugat (disqualificatie actoris exeptie) (Mahkamah Agung 2015).

Selain itu, bagi Cap Kaki Tiga pihak penggugat yang dalam hal ini adalah Russel Vince hanyalah seorang warga negara Inggris yang secara kebetulan mengetahui adanya pendaftaran Merek Cap Kaki Tiga di Indonesia yang dianggap menyerupai lambang negara Isle of Man, sehingga sebenarnya yang memiliki kepentingan dalam sengketa ini pada hakikatnya adalah Negara Isle of Man yang merasa lambang negaranya ditiru dan didaftar sebagai merek di Indonesia bukan individu. Merek Cap Kaki Tiga pertama kali didaftarkan di Singapura sejak Tahun 1937 dan negara Isle of Man selama ini tidak pernah mempersoalkan kepentingan tersebut, negara Isle of Man tidak merasa terganggu dengan keberadaan Merek Cap Kaki Tiga.

Sebagai salah satu negara yang telah bergabung dalam berbagai perjanjian perdagangan menyepakati kesepakatan mengenai Intellectual Property Right, secara tidak langsung menjadikan kita untuk patuh terhadap segala jenis aturan yang telah dibuat. Berbicara mengenai HKI tentunya kita tidak hanya akan berpegang pada satu Undang-Undang Republik Indonesia saja, melainkan terdapat banyak konvensi yang juga harus diadopsi dan dijadikan pertimbangan oleh negara dalam penyelesaian sengketa. Begitu pula dengan kasus Cap Kaki Tiga. Akan tetapi, jika dilihat berdasarkan putusan mengenai gagalnya gugatan Vince, Indonesia belum dapat melindungi hak-hak ekslusif dari ketentuan-ketentuan suatu Merek.

Bagi penulis, kasus ini sekiranya memberikan contoh mengenai bagaimana setiap perusahaan seharusnya mengambil keputusan dalam penggunaan merek dagang bagi usahanya. Sebab, dalam UU RI serta Hukum Internasional lainnya telah mengatur mengenai seperti apa merek tersebut serta merek yang dibatalkan pendaftaran, sehingga baik pihak pemberi izin merek dagang maupun pemilik merek dagang sepatutnya mengetahui hal tersebut sebelum beresiko pada pembatalan Merek ataupun sengketa. Selain itu, dalam kerjasama perdagangan setiap pemilik usaha juga membutuhkan ketelitian pada penetapan Merek barang/jasa, setiap merek yang sudah terdaftar sebelumnya tidak dapat didaftarkan dengan nama produk barang/jasa berbeda (Purwaka 2018). 


\section{TRIPs Agreement \& Paris Convention}

TRIPs adalah salah satu jembatan bagi setiap Negara anggota untuk ikut serta mengurangi pelanggaran-pelanggaran Kekayaan Intelektual, Article 1 (1) "Members shall give effect to the provisions of this Agreement. Members may, but shall not be obliged to, implement in their law more extensive protection than is required by this Agreement, provided that such protection does not contravene the provisions of this Agreement. Members shall be free to determine the appropriate method of implementing the provisions of this Agreement within their own legal system and practice". TRIPs memberikan kebebasan utnuk setiap Negara mengembangkan ketentuan hukum yang dapat diberlakukan, di Indonesia kesepakatan TRIPs sendiri diadipsi dalam UU No. 15 tahun 2001.

Dalam kesepakatan TRIPs yang diberlakukan oleh WTO, menjelaskan bagaimana setiap merek yang didaftarkan dilindungi secara hukum (Jened, Hak Kekayaan Intelektual: Penyalahgunaan Hak Eksklusif 2007), setiap usaha yang memiliki merek produk selaknya untuk mendaftarkan produknya sebelum bersengketa dengan pihak, sebab sengketa yang diajukan namun tidak terdaftar secara otomatis dibatalkan, sebagaimana dijelaskan dalam Article 15 (5); "Members shall publish each trademark either before it is registered or promptly after it is registered and shall afford a reasonable opportunity for petitions to cancel the registration. In addition, Members may afford an opportunity for the registration of a trademark to be opposed" (TRIPs 1994).

Jika dihubungkan dengan kasus Wen Ken Co. hal ini dinyatakan sah, sebab merek Cap Kaki Tiga sendiri merupakan merek dagang yang sudah didaftarkan produknya di Indonesia, disamping itu keberadaan Isle of Man sebagai sebuah wilayah yang lambang negaranya menyerupai logo produk Cap Kaki Tiga. Sama halnya dengan TRIPs, sebagai dasar hukum dan aturan terkait Merek, konvensi Paris juga menerangkan bahwa setiap Negara berhak dan wajib melindungi setiap merek yang mereka daftarkan, Article 6 "The countries of the Union undertake to protect service marks. They shall not be required to provide for the registration of such marks". Produk yang telah terdaftar memiliki perlindungan hukum, akan tetapi untuk setiap perlindungan Merek sesuai ketentuan yang diadopsi Indonesia adalah tidak dapat berupa Lambang/symbol dari suatu Negara.

TRIPs dan Paris Convention adalah landasan Indonesia dalam merumuskan UU mengenai perlindungan Kekayaan Intelektual, salah satunya adalah UU No. 15 Tahun 2001 mengenai Merek untuk produk Barang/Jasa. Dari landasan hukum tersebut Indonesia ataupun 
Negara lain kemudian melakukan pengembangan hukum sesuai yang berlaku di Negara masingmasing anggota dan berdasarkan kesepakatan. Kedua landasan ini kemudian menjelaskan sejauh mana Merek dan bagaimana suatu Merek dapat mendapatkan hak eksklusif namun tidak berbicara mengenai penyelesaian akhir dari sengketa Merek. Keberadaan TRIPs dan Paris Convention menganalisi bahwanya setiap merek yang menyerupai merek lain secara otomati gugur atau tidak dapat didaftarkan (Christman 2008).

\section{KESIMPULAN}

Setelah melalui beberapa proses penting di pengadilan, putusan Pengadilan Niaga RI bahwa pihak Cap Kaki Tiga dinyatakan untuk menarik produk tersebut di Indonesia, hal ini tentunya mengajarkan kita bahwa bentuk penjiplakan baik logo, lambang atau hal-hal lain yang berkaitan dengan merek dalam UU Indonesia adalah sesuatu yang penting dan patut diketahui oleh setiap pihak. Dalam kasus sengketa merek ini, adalah seharusnya Pengadilan Niaga melalui Mahkamah Agung mengeluarkan putusan tersebut, sebab sengketa Merek yang ada dapat berdampak pada konflik negara terkait yang nantinya akan mempengaruhi sistem politik, ekonomi dan pertahanan negara Indonesia dan Negara terkait.

Dalam upaya gugatan yang dilayangkan oleh Vince memiliki kendala dikarenakan banding yang dilakukan oleh pihak Wen Ken, hal ini mengingat bahwa Vince tidak memiliki hak kuasa sah untuk mengajukan gugatan serta Isle of Man bukan merupakan Negara anggota PBB serta produk minuman Cap Kaki Tiga Bukanlah produk asli Indonesia, sehingga Penggugat seharusnya mengeluarkan gugatan pada Negara asal perusahaan tersebut dan tidak dapat dikaitkan dengan peraturan hukum yang berlaku, sehingga kemudian Pengadilan Niaga Indonesia juga mengeluarkan putusan bahwa gugatan tersebut tidak sah dan dibatalkan. Namun, putusan akhir Pengadilan Niaga adalah dengan memberikan sangsi denda sebesar Rp. 10.000.000.,

Dari sengketa Merek inidapat kita simpulkan bahwasanya pendaftaran dan perlindungan Kekayaan Intelektual adalah proses yang layak diterima oleh setiap inventor berdasarkan pada hasil karya, ide kreatif dari suatu produk perusahaan tanpa harus menjiplak atau meniru logo/lambang pihak lain.

\section{DAFTAR PUSTAKA}

Christman, John. The Myth of Property. New York: Oxford Press, 2008.

Dianggoro, Wiratmo. Pembaharuan Undang-Undang Merek dan Dampaknya Bagi Dunia Bisnis. Jakarta: Yayasan Perkembangan Hukum Bisnis, 1997. 
DJKI Kemenkumham. "DJKI Kemenkumham." Direktorat Jendral Kekayaan Intelektual. January $\quad$ 14, 2001. https://dgip.go.id/images/ki-images/pdffiles/uu_pp1/uu_no_15_th_2001.pdf (accessed October 22, 2019).

Djumhana, Muhamad. Perkembangan Doktrin dan Teori Perlindungan Hak Kekayaan. Bandung: PT. Citra Aditya Bakti, 2006.

Indriyanto, Agung, and Irnie Mela Yusnita. Aspek Hukum Pendaftaran Merek. Rajawali Press, 2016.

Isle of Man Government. Isle of Man Government. August 13, 2009. https://www.gov.im/ (accessed November 18, 2019).

Jened, Rahmi. Hak Kekayaan Intelektual: Penyalahgunaan Hak Eksklusif. Surabaya: Airlangga Press, 2007.

—. Trademark Law. Jakarta: Kencana, 2015.

Kaligis, O.C. Teori-Praktik Merek dan Hak Cipta. Jakarta Timur: Alumni, 2012.

Mahkamah Agung. Putusan Mahmakah Agung. Putusan MA, Jakarta: Mahkamah Agung, 2015.

Peter, Achmad. "PERLINDUNGAN HUKUM TERHADAP MEREK ASING DI INDONESIA (Studi Kasus : Sengketa Merek Dagang Antara Wen Ken Drug Co ( PTE ) Ltd Lawan PT. Sinde Budi Sentosa)." Media Neliti, 2017: 4-6.

Purwaka, Tommy Hendra. Perlindungan Merek. Jakarta: Buku Obor, 2018.

Sulistiyono, Adi. Mekanisme Penyelesaian Sengketa HKI Hak atas Kekayaan Intelektual. Surakarta: UNS Press, 2004.

TRIPs. AGREEMENT ON TRADE-RELATED ASPECTS OF INTELLECTUAL PROPERTY RIGHTS. Constitution, San Fransisco: WTO, 1994.

Utomo, Tomi Suryo. Hak Kekayaan Intelektual (HKI) di Era Global, Sebuah Kajian Kontemporer. Yogyakarta: Graha Ilmu, 2009.

Wen Ken Group. About Us: Wen Ken Group. June 3, 2018. https://www.wenken.com (accessed September 12, 2019).

WIPO. "World Intellectual Property Right." Paris Convention. February 1, 1994. https://www.unido.org/sites/default/files/2014-04/Paris_Convention_0.pdf (accessed December 22, 2019).

World Trade Organization. "Intellectual Property Rights." World Trade Organizatio. February 2, 2018. https://www.wto.org/english/docs_e/legal_e/27-trips.pdf (accessed October 12, 2019).

-. Understanding WTO: Intellectual Property. September 4, 2017. https://www.wto.org/english/thewto_e/whatis_e/tif_e/agrm7_e.htm (accessed July 15, 2019). 